\title{
Bromofluorocarbene addition to 6-phenylbicyclo[3.2.0]hept-6-ene: characterization and formation mechanism of the products
}

\author{
Fatih Algi $^{\mathrm{a}, \mathrm{b}}$ and Metin Balci ${ }^{\mathrm{a}}{ }^{*}$ \\ ${ }^{a}$ Department of Chemistry, Middle East Technical University, 06531, Ankara,Turkey \\ ${ }^{b}$ Department of Chemistry, Onsekiz Mart University, 17020, Canakkale,Turkey \\ E-mail: $\underline{\text { mbalci@metu.edu.tr }}$
}

\begin{abstract}
Bromofluorocarbene addition to 6-phenylbicyclo[3.2.0]hept-6-ene provided fluoro-indanes such as 4,6-difluoro-5-phenylindane, 5,6-difluoro-4-phenylindane, 5,7-difluoro-4-phenylindane, 4bromo-6-fluoro-5-phenylindane and 5-bromo-6-fluoro-4-phenylindane. The characterization the formation mechanism of the products are discussed.
\end{abstract}

Keywords: Bromofluorocarbene, carbene addition, fluoro-indanes

\section{Introduction}

Carbenes are versatile intermediates that undergo insertion, rearrangement and facile addition reactions in which their importance to synthetic chemists can hardly be overestimated. ${ }^{1}$ The most common and thoroughly investigated reaction of carbenes is their addition to carbon-carbon double bonds, which provide ready access to cyclopropane derivatives and/or the corresponding rearranged products. Our contribution to this field is exemplified with the synthesis of bromofluoro cyclopropanes 1, 2 and 3, which were successfully converted to corresponding strained cyclic allenes and in turn stimulated us to attain further insights into this class of compounds. ${ }^{2-4}$ It is also worth noting that only a few carbene reactions with small-ring alkenes have been reported. ${ }^{5,6}$ Albeit numerous studies with open chain and cyclic alkenes larger than four-membered rings do in fact exist. Therefore, we have turned our attention to an unsymmetrical cyclobutene appendage $\mathbf{4}$ in connection with our work directed toward the synthesis of strained small-ring allenes. ${ }^{7}$ Herein, we would like to report the results of the bromofluoro carbene addition to 6-phenylbicyclo[3.2.0] hept-6-ene (4). ${ }^{8}$ 


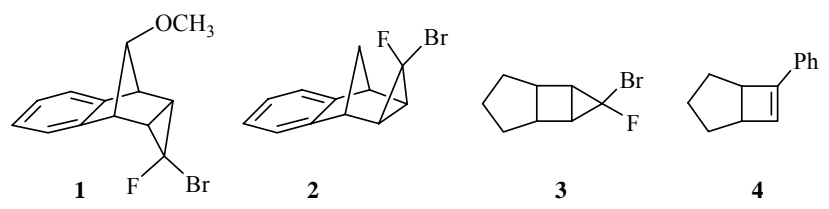

Figure 1

\section{Results and Discussion}

The starting material 4 was synthesized using a different route. Our research commenced with a three-step preparation of the known alcohol 5, which was obtained by the addition of dichloroketene to cyclopentene ${ }^{9}$ followed by dehalogenation and a reaction with phenyl magnesium bromide. ${ }^{10}$ The acid catalyzed dehydration of alcohol 5 with $p$-toluensulphonic acid resulted in the formation of cyclobutene 4 along with norcarene 6 in a ratio of 3:1 (Scheme 1). The norcarene derivative 6 was previously synthesized in quantitative yield by the reaction of a trace amount of $\mathrm{BF}_{3}\left(\mathrm{Et}_{2} \mathrm{O}\right)$ with of 1-phenyltricyclo[4.1.0.0 $\left.0^{2,7}\right]$ heptane. ${ }^{8 \mathrm{a}}$

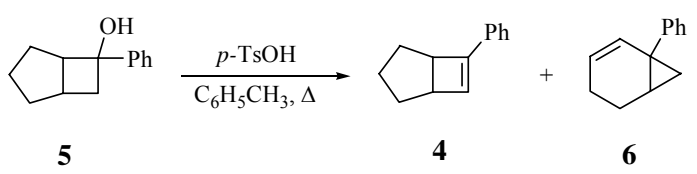

\section{Scheme 1}

The presence of a cyclopropane ring in $\mathbf{6}$ was proven spectroscopically based on the coupling constants between the proton and carbon nuclei $\left(J_{\mathrm{CH}}\right)$ of which its size strongly depends on the $\mathrm{s}$ fraction of the hybridization on the carbon. From the proton coupled ${ }^{13} \mathrm{C}-\mathrm{NMR}$ spectrum of the compound $\mathbf{6}$, the coupling constants between the cyclopropane carbons and protons $\left({ }^{1} J_{\mathrm{CH}}\right)$ were found to be 158.4 and $160.4 \mathrm{~Hz}$, which are characteristic of the cyclopropane carbons. ${ }^{11}$ After obtaining the desired precursor 4, it was treated with bromofluorocarbene under phase transfer conditions. The addition of bromofluorocarbene led to the formation of a mixture of products. GC-MS analysis indicated the formation of five different compounds with two $\mathrm{M}^{+}$ signals corresponding to $230(\mathbf{7 - 9})$ and $288 / 290(\mathbf{1 0}, \mathbf{1 1})$ in a ratio of $2: 4: 3: 1: 2$, respectively in high yield (80\%). After column chromatographic separations on silica gel containing $1 \%$ $\mathrm{AgNO}_{3}$, the compounds were characterized separately. (Scheme 2). 


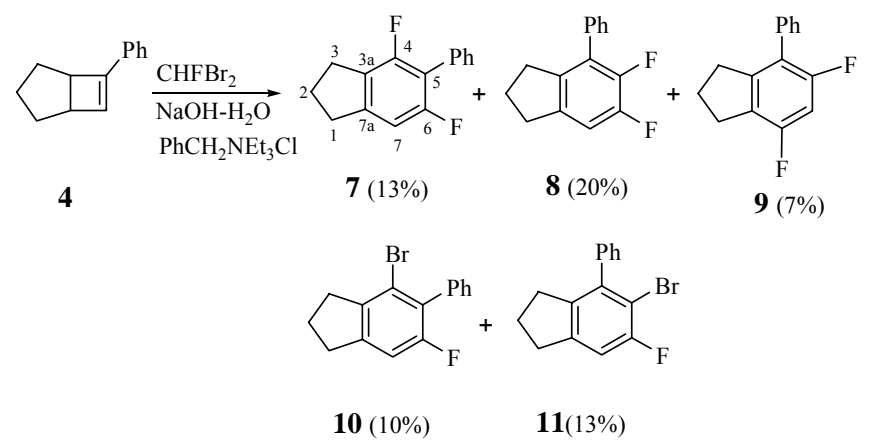

Scheme 2

The ${ }^{1} \mathrm{H}$ NMR spectrum of 7 indicated the presence of four sets of signals: a multiplet for the protons of the phenyl ring at 7.32-7.22 ppm, a doublet at $6.81 \mathrm{ppm}\left({ }^{3} J_{\mathrm{HF}}=9.0 \mathrm{~Hz}, \mathrm{H}_{7}\right)$ for the aromatic proton $\mathrm{H}_{7}$ along with a triplet at $2.85 \mathrm{ppm}\left({ }^{3} \mathrm{~J}=7.4 \mathrm{~Hz}, 4 \mathrm{H}\right)$ and a quintet at $2.06 \mathrm{ppm}$ $(\mathrm{J}=7.7 \mathrm{~Hz}, 2 \mathrm{H})$. The magnitude of the coupling constant $\left({ }^{3} J_{\mathrm{HF}}=9.0 \mathrm{~Hz}\right)$ suggested that this splitting arises from the interaction of the proton with a fluorine atom, which is located in the ortho position. ${ }^{12}$ Furthermore, the ${ }^{19}$ F-NMR spectrum has shown the presence of two fluorine atoms resonating at -118.8 and $-117.6 \mathrm{ppm}$, which are in the range of the chemical shifts of the aromatic fluorine atoms, giving rise in turn to doublets with a coupling constant of ${ }^{4} J_{\mathrm{FF}}=5.6 \mathrm{~Hz}$ in which its magnitude clearly suggests that the two fluorine atoms are located in meta position (Table 1).

Table 1. ${ }^{19}$ F-NMR chemical shifts (in ppm) and coupling constants (in Hz) with spin multiplities for fluoro-indane derivatives in $\mathrm{CDCl}_{3}$

\begin{tabular}{|c|c|c|c|}
\hline Compound & $\mathrm{F}_{\mathrm{a}}$ & $\mathrm{F}_{\mathrm{b}}$ & $J_{\mathrm{FF}}$ \\
\hline $\mathbf{7}$ & $-117.6(\mathrm{~d})$ & $-118.8(\mathrm{dd})$ & ${ }^{4} J=5.6$ \\
\hline $\mathbf{8}$ & $-140.6(\mathrm{dd})$ & $-146.2(\mathrm{dd})$ & ${ }^{3} J=20.3$ \\
\hline $\mathbf{9}$ & $-115.6(\mathrm{t})$ & $-117.4(\mathrm{t})$ & ${ }^{4} J=7.0$ \\
\hline $\mathbf{1 0}$ & $-113.3(\mathrm{~d})$ & -- & -- \\
\hline $\mathbf{1 1}$ & $-119.3(\mathrm{~d})$ & -- & -- \\
\hline
\end{tabular}

The comprehensive evidence for the structure 7 came from the proton-decoupled ${ }^{13} \mathrm{C}-\mathrm{NMR}$ spectrum in conjunction with the 2D-NMR (COSY, DEPT-135, HMQC and HMBC) experiments. The aromatic carbon $\mathrm{C}_{7}$ with an attached proton $(\delta 107.8)$, as shown by the DEPT experiment, is split into a doublet of doublets $\left({ }^{2} J_{\mathrm{CF}}=23.5\right.$ and $\left.{ }^{4} J_{\mathrm{CF}}=3.6 \mathrm{~Hz}\right)$. The magnitudes of these coupling constants indicate that this carbon $\left(\mathrm{C}_{7}\right)$ is ortho to a one fluorine atom and para to the other. The carbon holding phenyl ring resonates at $116.3 \mathrm{ppm}$ as triplets with a coupling constant $\left({ }^{2} J_{\mathrm{CF}}=19.0 \mathrm{~Hz}\right)$ which strongly suggests the presence of two fluorine atoms in the ortho position of this carbon. Similar C-F coupling constant arguments can be made for the doublet of doublets at $\delta 126.0\left(\mathrm{C}_{3 \mathrm{a}}, J_{\mathrm{CF}}=19.6\right.$ and $2.8 \mathrm{~Hz}$, ortho to one fluorine and para to the other $)$ and 
$146.8\left(\mathrm{C}_{7 \mathrm{a}}, J_{\mathrm{CF}}=9.5\right.$ and $7.8 \mathrm{~Hz}$, meta to both fluorine's $)$. The carbon atoms bonded to the fluorine's appear as a doublet of doublets centered at $\delta 159.5\left({ }^{1} J_{\mathrm{CF}}=245.1\right.$ and $\left.5.7 \mathrm{~Hz}\right)$, and $\delta$ $156.3\left({ }^{1} J_{\mathrm{CF}}=247.4\right.$ and $\left.7.8 \mathrm{~Hz}\right)$. The magnitude of the smaller C-F coupling constant in these carbon resonances unambiguously indicates that the two fluorine atoms are meta to one another. ${ }^{12}$ When taken together, these data firmly establish the structure of the previously unknown compound 7.

In a similar vein, the other products 8-11 were also characterized in which the spectroscopic data are given in the experimental section. The ortho position of the fluorine atoms in 8 and the meta position of fluorine atoms in $\mathbf{9}$ were easily determined from the coupling constants ${ }^{3} J_{\mathrm{FF}}=20.3 \mathrm{~Hz}$ for 8 and ${ }^{4} J_{\mathrm{FF}}=7.0 \mathrm{~Hz}$ for $\mathbf{9}$, respectively. To the best of our knowledge, these are the first examples of fluorine-substituted phenylindanes.

The observation of such products as 7-11 led us to propose a complex mechanistic scenario for the addition of bromofluorocarbene to cyclobutene 4, which presumably involves the initial formation of gem-bromofluoro cyclopropane 12. The bromofluoro carbene can approach the double bond in 4 in two different ways, which in turn leads to the formation of 12a (endo-fluoroexo-bromo) and 12b (endo-bromo-exo-fluoro). As 12 is formed, it undergoes electrocyclic ringexpansion in order to decrease the accommodated strain arising from the fusion of three small rings (three-, four-, and five-membered rings, respectively) (Schemes 3, 4 and 5).

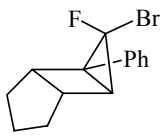

$12 \mathrm{a}$

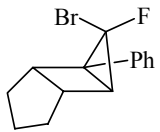

$12 b$

\section{Figure 2}

The formation of $\mathbf{1 2 b}$ where the bulky bromine atom is in the endo-position cannot be excluded due to the steric reasons (Figure 2). Recently, we have clearly shown that the bromofluoro carbene adds to benzonorbornadiene and bicyclohept-6-ene and forms the isomeric addition products $\mathbf{3} \mathbf{a} / \mathbf{3} \mathbf{b}$ and $\mathbf{2} \mathbf{a} / \mathbf{2} \mathbf{b}$, respectively (Scheme 3 ). Furthermore, we noticed that the isomers $\mathbf{3 b}$ and $\mathbf{2} \mathbf{b}$ underwent a ring-opening reaction, whereas the isomers 3a and 2a were stable under the given reaction conditions. Therefore, the formation of $\mathbf{2} \mathbf{b}$ and $\mathbf{3 b}$ also strongly supports the formation of the isomeric addition product $\mathbf{1 2 b}$.

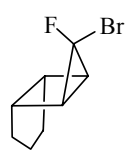

3a

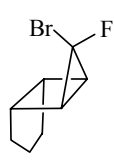

$3 \mathbf{b}$

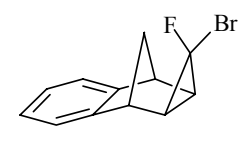

$2 \mathbf{a}$

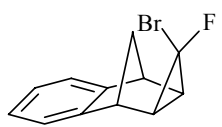

$2 \mathbf{b}$

Figure 3 
The ring opening reaction has been rationalized in terms of orbital symmetry conservation. ${ }^{13}$ It has been well established that the departing halide is the one that is in the endoposition. According to the Woodward-Hoffmann rules, the isomer 12b (Figure 2) should easily undergo a ring opening reaction, whereas the isomer 12a, where the bromine atom is in the exoposition, should be stable. ${ }^{4-6}$ However, careful examination of the reaction mixture did not reveal the presence of the isomer 12a. Therefore, we assume that the isomer 12a also easily undergoes ring-opening reaction. Recently, Lewis et $a l^{6 \mathrm{~b}}$ have demonstrated that the product obtained by the addition of difluorocarbene to 1,2-diphenylcyclobutene can easily undergo a ring opening reaction in spite of the fact that the departing halogen is a fluorine atom. We assume that the phenyl ring attached to the cyclopropane ring plays an important role in the ring opening reaction of 12a.

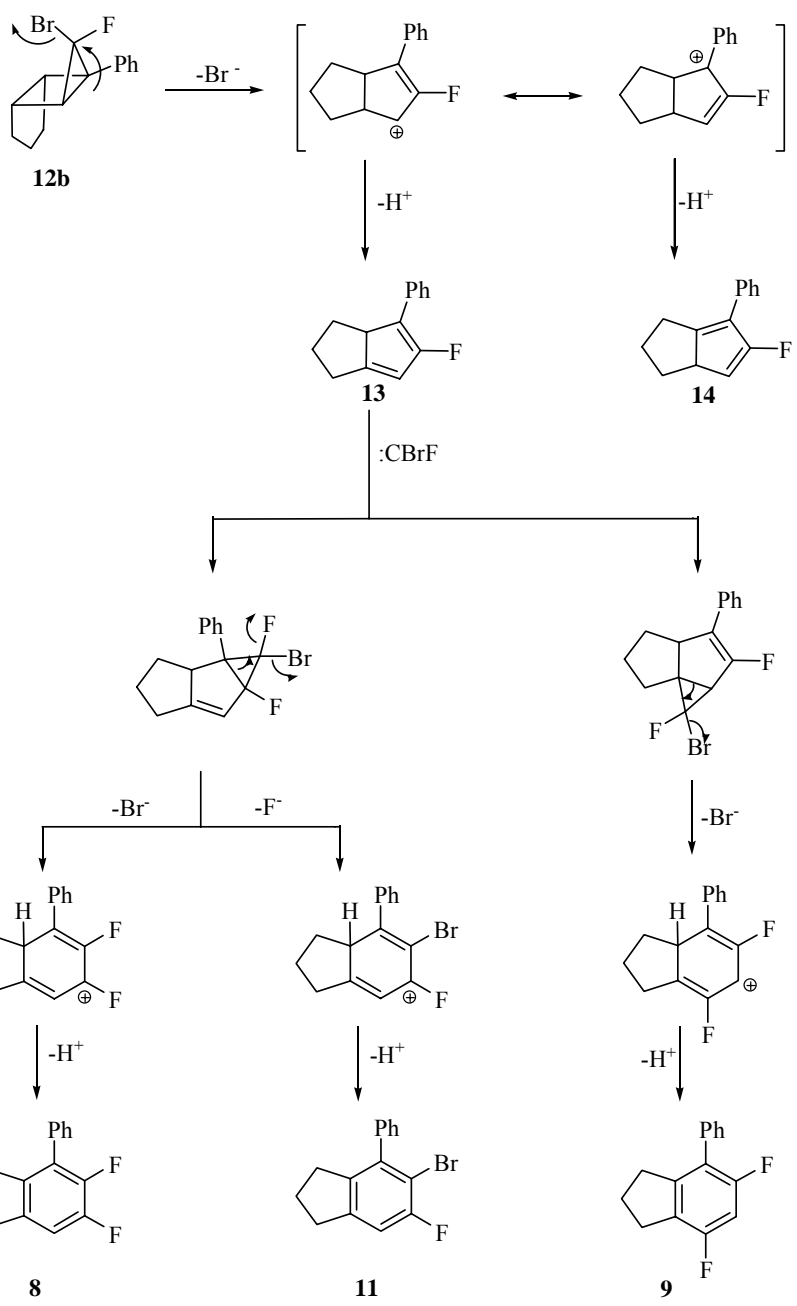

\section{Scheme 3}

Once the ring-expansion of $\mathbf{1 2 b}$ occurred, the two cationic intermediates formed could provide the cyclopentadienes $\mathbf{1 3}$ and $\mathbf{1 4}$ by the direct elimination of a proton (Scheme 3). After 
the formation of $\mathbf{1 3}$ and 14, the second addition of bromofluorocarbene might take place with two alternate paths for each, due to the presence of two unequal double bonds. The proposed mechanism with alternate paths is depicted for each case (Schemes 3 and 4). It is obvious that the presence of the cyclopentadiene $\mathbf{1 3}$ alone in the reaction can explain the formation of $\mathbf{8 , 9}$ and $\mathbf{1 1}$ but not $\mathbf{7}$ and 10. In an analogy, the formation of 7, 8, and $\mathbf{1 0}$ can be explained by the addition of bromofluoro carbene to the cyclopentadiene derivative 14 as depicted in Scheme 4. Furthermore, it is reasonable that cyclopentadienes such as $\mathbf{1 3}$ and $\mathbf{1 4}$ under reaction conditions are prone to undergo fast intramolecular 1,5-H-shifts before bromofluorocarbene attack takes place as it would further complicate the reaction mechanism.

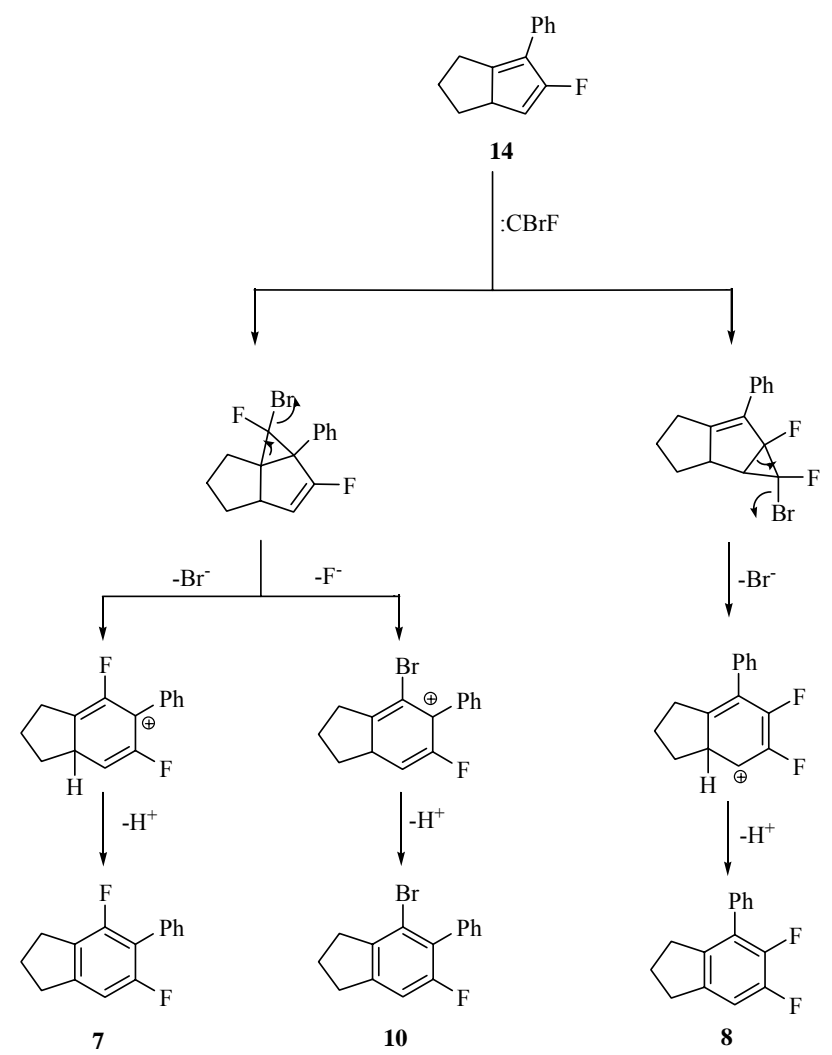

\section{Scheme 4}

The endo-fluoro-exo-bromo isomer 12a can easily undergo a ring-opening reaction where the departing halide is a fluorine atom. We assume that the phenyl substituent aids in fluoride ion loss. The second addition of bromofluorocarbene to the formed cyclopentadiene derivative 15 will result in the formation of $\mathbf{1 1}$ (Scheme 5). 


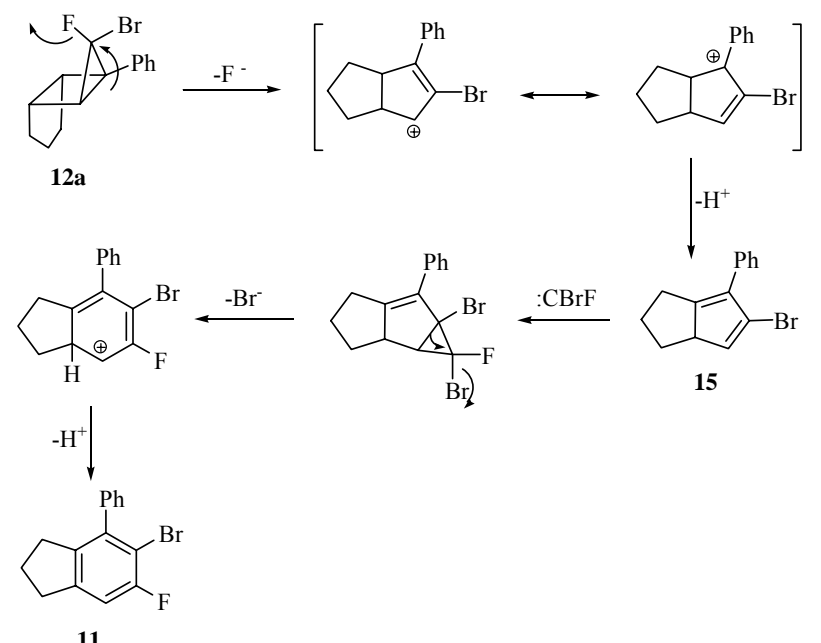

\section{Scheme 5}

\section{Conclusions}

In summary, the addition of bromofluorocarbene to cyclobutene 4 resulted in the formation of fluoro-indanes such as 7-11 by ring expansion in one step where gem-bromofluoro cyclopropane 12 is set as a reactive intermediate. Efforts to investigate the scope and limitations for the existence of bromofluorocyclopropanes en route to strained cyclic allenes are currently underway in our laboratory.

\section{Experimental Section}

General Procedures. Infrared spectra were recorded on a Mattson model 1000 FT-IR spectrometer. ${ }^{1} \mathrm{H}-,{ }^{13} \mathrm{C}$ - and ${ }^{19} \mathrm{~F}-\mathrm{NMR}$ spectra were recorded on 400,100 and $376.3 \mathrm{MHz}$ spectrometers (Bruker), respectively. Mass spectra (electron impact) were recorded at $70 \mathrm{eV}$. Column chromatography was performed on silica gel (60-200 mesh) from Merck Company. TLC was carried out on Merck $0.2 \mathrm{~mm}$ silica gel 60 F254 analytical aluminum plates.

\section{Compounds \& characterization}

Synthesis of 4 and 6. A solution of $7.5 \mathrm{~g}(40 \mathrm{mmol})$ alcohol 5 and $0.7 \mathrm{~g}(4 \mathrm{mmol}) p$-TsOH in $100 \mathrm{~mL}$ toluene was heated under reflux in a Dean-Stark trap, which was attached to a condenser. After $16 \mathrm{~h}$ the flask was allowed to cool to room temperature. The solution was washed first with $\mathrm{NaHCO}_{3}$ solution, and then with brine, dried over $\mathrm{CaCl}_{2}$. After evaporation of the solvent the residue was filtered on a silica gel $(50 \mathrm{~g})$ column eluting with hexane to give $4.1 \mathrm{~g}$ (24 mmol, yellowish liquid) of 4 and $1.0 \mathrm{~g}$ (6 mmol, colorless liquid) of 6 in a total yield of $75 \%$. 
6-Phenylbicyclo[3.2.0]hept-6-ene (4). ${ }^{8}$ Colorless liquid $\left(70{ }^{\circ} \mathrm{C}\right.$, bad temperature, 0.1 Torr $\left.{ }^{8 b}\right)$, ${ }^{1} \mathrm{H}$ NMR (400 MHz) $\delta 7.17-6.99$ (5H, m, aromatic), 5.95 (1H, bs, olefinic), 3.33-3.31 (1H, m, CH), 2.99-2.97 (1H, m, CH), 1.63-1.09 (6H, m); ${ }^{13} \mathrm{C}-\mathrm{NMR}(100.55 \mathrm{MHz}) \delta 146.2,134.1,128.4$, 128.0, 127.4, 124.8, 46.2, 44.0, 26.9, 26.3, 23.8.

1-Phenylbicyclo[4.1.0]hept-2-ene (6). ${ }^{8 \mathrm{a}}$ Colorless liquid, ${ }^{1} \mathrm{H}-\mathrm{NMR}(400 \mathrm{MHz}) \delta 7.21-7.17(4 \mathrm{H}$, $\mathrm{m}$, aromatic), 7.10-7.04 (1H, m, aromatic), $6.08(1 \mathrm{H}, \mathrm{dd}$, A-part of AB system, $J=10.0-2.2 \mathrm{~Hz}$, $\mathrm{H}-2), 5.48$ (1H, ddd, B-part of AB system, $J=10.0,6.4$ and 2.2 Hz, H-3), 2.02-1.92 (2H, m, methylenic), 1.79-1.67 (2H, m, methylenic), 1.44-1.42 (1H, m, H-6), $1.27(1 \mathrm{H}, \mathrm{dd}, J=8.5$ and $4.9 \mathrm{~Hz}, \mathrm{H}-7), 1.04(1 \mathrm{H}, \mathrm{bt}, J=4.9 \mathrm{~Hz}, 1 \mathrm{H}) ;{ }^{13} \mathrm{C}-\mathrm{NMR}(100.55 \mathrm{MHz}) \delta 146.5(\mathrm{~s}), 133.0\left(\mathrm{~d},{ }^{1} J_{\mathrm{CH}}=\right.$ $151.4 \mathrm{~Hz}), 128.7\left(\mathrm{~d},{ }^{1} J_{\mathrm{CH}}=158.0 \mathrm{~Hz}\right), 127.5\left(\mathrm{~d},{ }^{1} J_{\mathrm{CH}}=156.0 \mathrm{~Hz}\right), 126.0\left(\mathrm{~d},{ }^{1} J_{\mathrm{CH}}=151.7 \mathrm{~Hz}\right)$, $123.2\left(\mathrm{~d},{ }^{1} J_{\mathrm{CH}}=157.3 \mathrm{~Hz}\right), 25.6\left(\mathrm{~d},{ }^{1} J_{\mathrm{CH}}=158.4 \mathrm{~Hz}\right), 24.3,20.8\left(\mathrm{t},{ }^{1} J_{\mathrm{CH}}=127.6 \mathrm{~Hz}\right), 19.0(\mathrm{t}$, $\left.{ }^{1} J_{\mathrm{CH}}=126.2 \mathrm{~Hz}\right), 18.4\left(\mathrm{t},{ }^{1} J_{\mathrm{CH}}=160.4 \mathrm{~Hz}\right) ; \mathrm{MS}\left(\mathrm{m} / \mathrm{z}\right.$, relative intensity): $169\left(\mathrm{M}^{+}-\mathrm{H}, 65\right), 153$ (100), 141 (90), 127 (65), 114 (45), 101 (15), 90 (30), 76 (45), 50 (35).

Bromofluorocarbene Addition to 4. To a magnetically stirring solution of $1.0 \mathrm{~g}$ (6 mmol) olefin 4, $2.8 \mathrm{~g}$ (14.8 mmol) $\mathrm{CHBr}_{2} \mathrm{~F}$ and $0.25 \mathrm{~g}$ (1 mmol) $\mathrm{PhCH}_{2} \mathrm{NEt}_{3} \mathrm{Cl}$ in $100 \mathrm{ml} \mathrm{CH}_{2} \mathrm{Cl}_{2}$, a

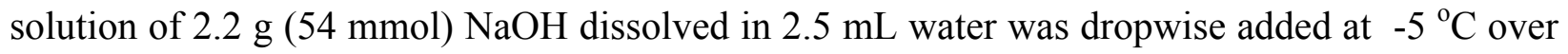
a period of $2 \mathrm{~h}$. After stirring for an additional $8 \mathrm{~h}$ at room temperature, the reaction mixture was diluted with $250 \mathrm{~mL}$ water and extracted with $\mathrm{CH}_{2} \mathrm{Cl}_{2}(3 \times 100 \mathrm{~mL})$, dried over $\mathrm{MgSO}_{4}$, and the solvent was removed under reduced pressure. Repeated column chromatography of the residue $\left(1 \% \mathrm{AgNO}_{3}\right.$-silica gel, $\left.100 \mathrm{~g}\right)$ with hexane as eluant gave compounds 7 (0.20 g, 13\%, colorless liquid), 8 (0.40 g, 27\%, colorless liquid), 9 (0.30 g, 20\%, colorless liquid), 10 (0.10 g, 7\%, colorless liquid), and $\mathbf{1 1}(0.20 \mathrm{~g}, 13 \%$, colorless liquid).

4,6-Difluoro-5-phenylindane (7). Colorless liquid, ${ }^{1} \mathrm{H}-\mathrm{NMR}(400 \mathrm{MHz}) \delta$ 7.32-7.30 (4H, m, aromatic), 7. 26-7.23 (1H, m, aromatic) $6.81\left(1 \mathrm{H}, \mathrm{d},{ }^{3} J_{\mathrm{HF}}=9.0 \mathrm{~Hz}, \mathrm{H}-7\right), 2.85(4 \mathrm{H}, t, J=7.4 \mathrm{~Hz}$, $\mathrm{H}-1$ and H-3), 2.06 (2H, J=7.4 Hz, H-2); ${ }^{13} \mathrm{C}-\mathrm{NMR}$ (The multiplicities of the carbon resonances were determined from the DEPT spectra) $\left(100.55 \mathrm{MHz}, \mathrm{CDCl}_{3}\right) \delta 159.5\left(\mathrm{dd},{ }^{1} J_{\mathrm{CF}}=245.1 \mathrm{~Hz}\right.$, $\left.{ }^{3} J_{\mathrm{CF}}=5.7 \mathrm{~Hz}, \mathrm{C}-4\right), 156.3\left(\mathrm{dd},{ }^{1} J_{\mathrm{CF}}=247.4 \mathrm{~Hz},{ }^{3} J_{\mathrm{CF}}=7.8 \mathrm{~Hz}, \mathrm{C}-6\right), 146.8\left(\mathrm{dd},{ }^{3} J_{\mathrm{CF}}=9.5 \mathrm{~Hz}\right.$, $\left.{ }^{3} J_{\mathrm{CF}}=7.8 \mathrm{~Hz}, \mathrm{C}-7 \mathrm{a}\right), 130.8$ (d, C-2 2 arom.), 130.4 (s, C-1 arom.), 128.5 (d, C-3 $\left.3_{\text {arom }}\right), 128.1$ (d, C-4 arom), $126.0\left(\mathrm{dd},{ }^{2} J_{\mathrm{CF}}=19.6 \mathrm{~Hz},{ }^{4} J_{\mathrm{CF}}=2.8 \mathrm{~Hz}, \mathrm{C}-3 \mathrm{a}\right), 116.3\left(\mathrm{t},{ }^{2} J_{\mathrm{CF}}=19.0 \mathrm{~Hz}, \mathrm{C}-5\right), 107.8\left(\mathrm{dd},{ }^{2} J_{\mathrm{CF}}\right.$ $\left.=23.5 \mathrm{~Hz},{ }^{4} J_{\mathrm{CF}}=3.6 \mathrm{~Hz}, \mathrm{C}-7\right), 33.8(\mathrm{t}, \mathrm{C}-1), 29.0$ (t, C-3), 25.8 (t, C-2); ${ }^{19} \mathrm{~F}-\mathrm{NMR}(376.2 \mathrm{MHz}$, $\left.\mathrm{CDCl}_{3}\right) \delta-117.6\left(\mathrm{~d},{ }^{4} J_{\mathrm{FF}}=5.6 \mathrm{~Hz}, \mathrm{~F}-\mathrm{C}-6\right),-118.8\left(\mathrm{t},{ }^{4} J_{\mathrm{FF}}={ }^{3} J_{\mathrm{HF}} 7.1 \mathrm{~Hz}, \mathrm{~F}-\mathrm{C}-4\right) ; \mathrm{MS}(\mathrm{m} / \mathrm{z}$, relative intensity): $230\left(\mathrm{M}^{+}, 70\right), 152$ (25), 132 (10), 100 (10), 76 (10), 50 (7). IR $\left(\mathrm{CHCl}_{3}, \mathrm{~cm}^{-1}\right): 3084$ (sh), 3056 (sh), 3021 (m), 2951 (s), 2944 (sh), 2909 (sh), 2853 (s), 2832 (sh), 1644 (m), 1567 (m), 1462 (s), 1420 (s), 1329 (m), 1266 (w) , 1106v(m), 1022 (m), 847 (m), 763 (m), 686 (m), 560 (w). Anal. Calcd. for $\mathrm{C}_{15} \mathrm{H}_{12} \mathrm{~F}_{2}$ : C, 78.24; H, 5.25. Found: C, 77.85; H, 5.11.

5,6-Difluoro-4-phenylindane (8). Colorless liquid, ${ }^{1} \mathrm{H}-\mathrm{NMR}(400 \mathrm{MHz}) \delta 7.46-7.35(5 \mathrm{H}, \mathrm{m}$, aromatic), $6.88\left(1 \mathrm{H}, \mathrm{dd},{ }^{3} J_{\mathrm{HF}}=9.4 \mathrm{~Hz},{ }^{4} J_{\mathrm{HF}}=7.1 \mathrm{~Hz}, \mathrm{H}-7\right), 2.95(2 \mathrm{H}, \mathrm{t}, J=7.3 \mathrm{~Hz}), 2.80(2 \mathrm{H}, \mathrm{t}, J$ $=7.3 \mathrm{~Hz}), 2.08(2 \mathrm{H}$, qui, $J=7.3 \mathrm{~Hz}) ;{ }^{13} \mathrm{C}-\mathrm{NMR}(100 \mathrm{MHz}) \delta 150.1\left(\mathrm{dd},{ }^{1} J_{\mathrm{CF}}=245.0 \mathrm{~Hz},{ }^{2} J_{\mathrm{CF}}=\right.$ $14.5 \mathrm{~Hz}, \mathrm{C}-5), 146.9\left(\mathrm{dd},{ }^{1} J_{\mathrm{CF}}=243.7 \mathrm{~Hz},{ }^{2} J_{\mathrm{CF}}=13.7 \mathrm{~Hz}, \mathrm{C}-6\right), 139.4\left(\mathrm{dd},{ }^{3} J_{\mathrm{CF}}=6.0 \mathrm{~Hz},{ }^{4} J_{\mathrm{CF}}=\right.$ $3.5 \mathrm{~Hz}, \mathrm{C}-3 \mathrm{a}$ ), 138.7 (bs, C-7a), 134.4 (s, C-1 arom.), 130.0 (d), 128.6 (d), 127.8 (d), 127.7 (bd, 
$\left.{ }^{2} J_{\mathrm{CF}}=10.4 \mathrm{~Hz}, \mathrm{C}-4\right), 111.9\left(\mathrm{~d},{ }^{2} J_{\mathrm{CF}}=17.5 \mathrm{~Hz}, \mathrm{C}-7\right), 33.4(\mathrm{C}-1), 32.8(\mathrm{C}-3), 26.3(\mathrm{C}-2) ;{ }^{19} \mathrm{~F}-\mathrm{NMR}$ $\left(376.3 \mathrm{MHz}, \mathrm{CDCl}_{3}\right) \delta-140.6\left(\mathrm{dd},{ }^{3} J_{\mathrm{FF}}=20.3 \mathrm{~Hz},{ }^{3} J_{\mathrm{FH}}=9.8 \mathrm{~Hz} \mathrm{~F}-\mathrm{C}-6\right),-146.2\left(\mathrm{dd},{ }^{3} J_{\mathrm{FF}}=20.3\right.$ $\mathrm{Hz},{ }^{3} J_{\mathrm{FH}}=7.2 \mathrm{~Hz}$ F-C-5); MS (m/z, relative intensity): $230\left(\mathrm{M}^{+}, 95\right), 152$ (50), 132 (12), 100 (15), 76 (8), 62 (5), 50 (10). IR ( $\left.\mathrm{CHCl}_{3}, \mathrm{~cm}^{-1}\right)$ : 3056 (w), 2958 (s), 2951 (s), $2846(\mathrm{~m}), 1700(\mathrm{w})$, 1616 (s) , 1476 (vs), 1441 (s), 1343 (s), 1203 (sh), 1238 (w), 1126 (m), 1071 (w), 1029 (w), 868 (m), 770 (s), $700(\mathrm{~s}), 644$ (w), 574 (w). Anal. Calcd. for $\mathrm{C}_{15} \mathrm{H}_{12} \mathrm{~F}_{2}$ : C, 78.24; H, 5.25. Found: C, 78.51; H, 5.09 .

5,7-Difluoro-4-phenylindane (9). Colorless liquid, ${ }^{1} \mathrm{H}-\mathrm{NMR}(400 \mathrm{MHz}) \delta$ 7.36-7.22 $(5 \mathrm{H}, \mathrm{m}$, aromatic), $6.62\left(1 \mathrm{H}, \mathrm{t},{ }^{3} J_{\mathrm{HF}}=9.2 \mathrm{~Hz}, \mathrm{H}-6\right), 2.87(2 \mathrm{H}, \mathrm{t}, J=7.4 \mathrm{~Hz}, \mathrm{H}-1), 2.75(2 \mathrm{H}, \mathrm{t}, J=7.4 \mathrm{~Hz}, \mathrm{H}-$ 3), $2.01(2 \mathrm{H}$, qui, $J=7.4 \mathrm{~Hz}, 2 \mathrm{H}) ;{ }^{13} \mathrm{C}-\mathrm{NMR}(100 \mathrm{MHz}) \delta 159.1\left(\mathrm{dd},{ }^{1} J_{\mathrm{CF}}=244.9 \mathrm{~Hz},{ }^{3} J_{\mathrm{CF}}=10.4\right.$ $\left.\mathrm{Hz}, \mathrm{C}_{5}\right), 158.1\left(\mathrm{dd},{ }^{1} J_{\mathrm{CF}}=246.7 \mathrm{~Hz},{ }^{3} J_{\mathrm{CF}}=12.7 \mathrm{~Hz}, \mathrm{C}-7\right), 147.7\left(\mathrm{t},{ }^{3} J_{\mathrm{CF}}=5.2 \mathrm{~Hz}, \mathrm{C}-3 \mathrm{a}\right), 134.6(\mathrm{~s})$ (C-1 $\left.1_{\text {arom }}\right), 129.8$ (d), 128.5 (d), 128.1 (d) , 125.7 (dd, $\left.{ }^{2} J_{\mathrm{CF}}=14.9,{ }^{4} J_{\mathrm{CF}}=3.3 \mathrm{~Hz}, \mathrm{C}-7 \mathrm{a}\right), 122.4$ (dd, $\left.{ }^{2} J_{\mathrm{CF}}=16.2,{ }^{4} J_{\mathrm{CF}}=3.1 \mathrm{~Hz}, \mathrm{C}-4\right), 102.1\left(\mathrm{dd},{ }^{2} J_{\mathrm{CF}}=27.5\right.$ and $\left.24.7 \mathrm{~Hz}, \mathrm{C}-6\right), 33.6(\mathrm{t}, \mathrm{C}-3), 29.8(\mathrm{t}, \mathrm{C}-$ 1), $26.0(\mathrm{t}, \mathrm{C}-2) ;{ }^{19} \mathrm{~F}-\mathrm{NMR}\left(376.3 \mathrm{MHz}, \mathrm{CDCl}_{3}\right) \delta-115.6\left(\mathrm{t},{ }^{3} J_{\mathrm{FH}}={ }^{4} J_{\mathrm{FF}}=7.0 \mathrm{~Hz}\right),-117.4$ (br.t, $\left.{ }^{3} J_{\mathrm{FH}}={ }^{4} J_{\mathrm{FF}}=7.0 \mathrm{~Hz}\right) ; \mathrm{MS}\left(\mathrm{m} / \mathrm{z}\right.$, relative intensity): $230\left(\mathrm{M}^{+}, 80\right), 152(25), 132(8), 100$ (10), 76 (5), 62 (3), 50 (7). IR ( $\left.\mathrm{CHCl}_{3}, \mathrm{~cm}^{-1}\right)$ : 2944 (sh), 2923 (m), 2846 (w), 1721 (w), 1658 (w), 1609 (w), 1455 (w), $1371(\mathrm{w}), 1287$ (w), 1217 (m), 1113 (w), 882 (w), 763 (vs), 707 (w), 679 (w). Anal. Calcd. for $\mathrm{C}_{15} \mathrm{H}_{12} \mathrm{~F}_{2}$ : C, 78.24; H, 5.25. Found: C, 78.15; H, 5.13.

4-Bromo-6-fluoro-5-phenylindane (10). Colorless liquid, ${ }^{1} \mathrm{H}-\mathrm{NMR}(400 \mathrm{MHz}) \delta$ 7.36-7.27 (3H, m, aromatic), $7.19\left(2 \mathrm{H}, \mathrm{bd}, J=7.9 \mathrm{~Hz}\right.$, aromatic), $6.87\left(1 \mathrm{H}, \mathrm{d},{ }^{3} J_{\mathrm{HF}}=8.7 \mathrm{~Hz}, \mathrm{H}-7\right), 2.99(2 \mathrm{H}$, t, $\left.J=7.5 \mathrm{~Hz},-\mathrm{CH}_{2}-\right), 2.90\left(2 \mathrm{H}, \mathrm{t}, J=7.5 \mathrm{~Hz},-\mathrm{CH}_{2}-\right), 2.08(2 \mathrm{H}$, qui, $J=7.5 \mathrm{~Hz}, \mathrm{H}-2) ;{ }^{13} \mathrm{C}-\mathrm{NMR}$ $(100.55 \mathrm{MHz}) \delta 159.3\left(\mathrm{~d},{ }^{1} J_{\mathrm{CF}}=245.4 \mathrm{~Hz}, \mathrm{C}-6\right), 145.5\left(\mathrm{~d},{ }^{3} J_{\mathrm{CF}}=8.5 \mathrm{~Hz}, \mathrm{C}-7 \mathrm{a}\right), 140.9\left(\mathrm{~d},{ }^{4} J_{\mathrm{CF}}=\right.$ $2.8 \mathrm{~Hz}, \mathrm{C}-3 \mathrm{a}), 135.4$ (s, C-1 arom.), 130.6 (d, C-2 arom.), 128.5 (d, $\left.{ }^{2} J_{\mathrm{CF}}=26.9 \mathrm{~Hz}, \mathrm{C}-5\right), 128.3$ (d, C$\left.3_{\text {arom. }}\right), 128.2$ (4, C-4 arom.), $121.6\left(\mathrm{~d},{ }^{3} J_{\mathrm{CF}}=3.9 \mathrm{~Hz}, \mathrm{C}-4\right), 111.0\left(\mathrm{~d},{ }^{2} J_{\mathrm{CF}}=24.0 \mathrm{~Hz}, \mathrm{C}-7\right), 35.1$ (t, C1), 34.6 (t, C-3), 24.8 (t, C-2); ${ }^{19} \mathrm{~F}-\mathrm{NMR}\left(376.3 \mathrm{MHz}, \mathrm{CDCl}_{3}\right) \delta-113.3\left(\mathrm{~d},{ }^{3} J_{\mathrm{FH}}=24.0 \mathrm{~F}-\mathrm{C}-6\right)$; MS (m/z, relative intensity): 290/288 (M+1, 95), 210 (30), 195 (70), 182 (55), 168 (10), 132 (30), 103 (25), 91 (25), 50 (10). IR ( $\left.\mathrm{CHCl}_{3}, \mathrm{~cm}^{-1}\right): 2958$ (sh), $2951(\mathrm{sh}), 2916(\mathrm{~m}), 2846(\mathrm{w}), 1658(\mathrm{w})$ , 1609 (m), 1399 (w), 1217 (m), 1113 (w), 1092 (w), 819 (w), 777 (vs), 651 (w). Anal. Calcd. for $\mathrm{C}_{15} \mathrm{H}_{12} \mathrm{BrF}$ : C, 61.88; H, 4.15. Found: C, 61.43; H, 4.06.

5-Bromo-6-fluoro-4-phenylindane (11). Colorless liquid, ${ }^{1} \mathrm{H}-\mathrm{NMR}(400 \mathrm{MHz}) \delta$ 7.34-7.22 (5H, m, aromatic), $7.07\left(1 \mathrm{H}, \mathrm{d},{ }^{2} J_{\mathrm{HF}}=9.2 \mathrm{~Hz}, \mathrm{H}-7\right), 2.89(\mathrm{t}, J=7.4 \mathrm{~Hz}, \mathrm{H}-1), 2.85(2 \mathrm{H}, \mathrm{t}, J=7.4$ $\mathrm{Hz}, \mathrm{H}-3), 1.98$ (2H, qui, $J=7.4 \mathrm{~Hz}, \mathrm{H}-2) ;{ }^{13} \mathrm{C}-\mathrm{NMR}(100 \mathrm{MHz}) \delta 158.8\left(\mathrm{~d},{ }^{1} J_{\mathrm{CF}}=247.0 \mathrm{~Hz}, \mathrm{C}-6\right)$, 146.0 (s, C-3a), 140.3 (s, C-7a), 134.4 (s, C-1 arom), 129.7 (d, C-3 $3_{\text {arom }}$ ), 128.5 (d,C-2 arom), 127.9 (d, C-4 arom), $125.6\left(\mathrm{~d},{ }^{2} J_{\mathrm{CF}}=16.3 \mathrm{~Hz}, \mathrm{C}-5\right), 118.3\left(\mathrm{~d},{ }^{3} J_{\mathrm{CF}}=10.7 \mathrm{~Hz}, \mathrm{C}-4\right), 117.4\left(\mathrm{~d},{ }^{2} J_{\mathrm{CF}}=26.9 \mathrm{~Hz}\right.$, C-7), 34.5 (t, C-3), $34.4\left(\mathrm{~d},{ }^{4} J_{\mathrm{CF}}=2.9 \mathrm{~Hz}, \mathrm{C}-1\right), 25.2(\mathrm{t}, \mathrm{C}-2) ;{ }^{19} \mathrm{~F}-\mathrm{NMR}\left(376.3 \mathrm{MHz}, \mathrm{CDCl}_{3}\right) \delta$ $119.3\left(\mathrm{~d},{ }^{3} J_{\mathrm{FH}}=9.4 \mathrm{~Hz}\right) ; \mathrm{MS}\left(\mathrm{m} / \mathrm{z}\right.$, relative intensity): 290/288 (M+ $\left.{ }^{+}, 85\right), 210(45), 195(65), 182$ (55), 132 (40), 103 (30), 91 (35), 76 (20), 50 (15), 43 (50). IR ( $\left.\mathrm{CHCl}_{3}, \mathrm{~cm}^{-1}\right): 2959$ (m), 2944 (m), $2916(\mathrm{~s}), 2853(\mathrm{~m}), 1679(\mathrm{~m}), 1623(\mathrm{~s}), 1455(\mathrm{~m}), 1406(\mathrm{w}), 1371(\mathrm{w}), 1217(\mathrm{w}), 1126(\mathrm{~m})$, 1092 (w), 770 (vs), 707 (w), 644 (w), 602 (w). Anal. Calcd. for $\mathrm{C}_{15} \mathrm{H}_{12} \mathrm{BrF}$ : C, 61.88; H, 4.15. Found: C, 61.47; H, 4.29. 


\section{Acknowledgements}

The authors are indebted to TÜBİTAK -MİSAG (Project Nr. 216) and TÜBA for financial support of this work.

\section{References and Notes}

1. (a) Brinker, U.H. In Advances in Carbene Chemistry; JAI: New York, 1994. (b) Sydnes, L. K. Chem. Rev. 2003, 103, 1133-1150. (c) M. Fedorynski, Chem. Rev. 2003, 103, 1099-1132.

2. Azizoğlu, A.; Balci, M. unpublished results.

3. Özen, R.; Balci, M. Tetrahedron 2002, 58, 3079.

4. Algi, F.; Özen, R.; Balci, M. Tetrahedron Lett. 2002, 43, 3129.

5. (a) For the addition of dihalocarbenes to cyclopropenes see: Weber, J.; Lu, X.; Brinker, U. H. Tetrahedron Lett. 1992, 33, 4537. (b) Weber, J.; Brinker, U. H. Angew. Chem. Int. Ed., 1997, 36, 1623.

6. For other examples of the addition of dihalocarbenes to cyclobutenes see: (a) Wagner, R. A.; Weber, J.; Brinker, U. H. Chem. Lett. 2000, 246. (b) Morrison, H. M.; Rainbolt, J. E.; Lewis, S. B. Org. Lett. 2002, 4, 3871. (c) Algi, F.; Hökelek, T.; Balci, M. J. Chem. Res. (S), 2004, 10,658 .

7. (a) Azizoglu, A.; Özen, R.; Hökelek, T.; Balci, M. J. Org. Chem. 2004, 69, 1202. (b) Balci, M.; Taskesenligil, Y. In Advances in Strained and Interesting Organic Molecules; Halton, B., Ed.; JAI Press Inc: Stamford, CT, 2000; Vol.8, pp 43-81. (c) Balci, M.; Harmandar, M. Tetrahedron Lett. 1984, 2, 237. (d) Balci, M.; Jones, W.M. J. Am. Chem. Soc. 1981, 103, 2874.

8. (a) Fujita, K.; Nakamura, T.; Matsui, K.; Shono, T. Tetrahedron Lett. 1975, 29, 2441. (b) Christl, M.; Stangl, R.; Jelinek-Fink, H. Chem. Ber. 1992, 125, 485.

9. Montaigne, R.; Ghosez, L.; Roussel, A.; Vanlierde, H.; Mollet, P. Tetrahedron, 1971, 27, 615.

10. (a) Wiberg, Kenneth B.; Chen, Wan-Fang. J. Am. Chem. Soc. 1974, 96, 3900-3905. (b) Christl, M.; Gerstner, E.; Kemmer, R.; Llewellyn, G.; Bentley, T. W. Chem. Ber. 1994, 127, 367.

11. Balci, M. Basic ${ }^{1} H$ - and ${ }^{13} C-N M R$ Spectroscopy; Elsevier, 2005.

12. (a) Mooney E. F. in An Introduction to ${ }^{19} F-N M R$ Spectroscopy; Heyden and Son Ltd.: London, UK, 1970; pp 39-53. (b) Kalinowski, H. O.; Berger, S.; Braun, S. Carbon-13 NMR Spectroscopy; Wiley and Sons: Chichester, UK, 1984; pp 581-585.

13. Woodward, R. B.; Hoffmann R. The Conservation of Orbital Symmetry; Verlag Chemie, Weinheim, 1970. 